\title{
ARAŞTIRMA / RESEARCH \\ Özel yetenek sınavına giren adayların çizim başarısı ile el anatomisi arasındaki ilişki
}

\author{
Relationship between drawing success and hand anatomy of candidates entering \\ special aptitude exam
}

Ayşe Gül Kabakc1 ${ }^{1}$, Handan Narin ${ }^{2}$, Ahmet Hilmi Yücel ${ }^{1}$

${ }^{1}$ Çukurova Üniversitesi Tip Fakültesi Anatomi Anabilim Dalı, Adana, Turkey

${ }^{2}$ Çukurova Üniversitesi Eğitim Fakültesi Güzel Sanatlar Eğitimi Bölümü Resim-İş Eğitimi Anabilim Dalı, Adana, Turkey

\begin{abstract}
Purpose: The research aims to determine whether there is a statistically significant relation between the drawing exam scores got by candidates entering the special aptitude exams in the Fine Arts Education and their hand anatomy (phalange lengths, carpus diameter, circumference and width of motion measurements) or not.
\end{abstract}

Materials and Methods: This study includes the candidates who entered Special Aptitude Exams organized by Department of Fine Arts Education, Faculty of Education of a university in Turkey. Phalanges length, wrist diameter, circumference and motion width were measured using digital caliper, inflexible scales and digital inclinometer.

Results: In our study, 161 students (60 boys, 101 girls) aged 18-25 years were included. There are 49 female and 35 male students who score fifty or more in the drawing examination and 52 female and 25 male students with scores of forty-nine and under in this study. A significant difference was not obtained when the anthropometric features of those who were fifty or more and those who were below forty-nine were below the drawing achievement score.

Conclusion: This study has revealed that there are many factors that influence the drawing skill. Also reached the conclusion that it is difficult to say that the effect of drawing on the success of the single anthropometric standards.

Key words: Hand anatomy, special aptitude exams, drawing, drawing success.
Öz

Amaç: Bu çalışma, Resim-İs Eğitimi özel yetenek sınavına giren adaylarin el anatomisinin (parmak uzunlukları, el bileği çap, çevre ve hareket genişliği ölçümleri) desen sınavında aldıkları puan ile ilişkisi olup olmadı̆̆ını ortaya koymayı amaçlamaktadır.

Gereç ve Yöntem: Türkiye'deki bir üniversitenin Eğitim Fakültesi Güzel Sanatlar Eğitimi Bölümü Resim-İș Eğitimi Anabilim Dalı Özel Yetenek Sinavi'na giren adaylar çalışmaya dahil edilmiştir. Öğrencilerin dijital kaliper, esnek olmayan mezura ve dijital inklinometre kullanılarak parmak uzunlukları, el bileği çapı, çevresi ve hareket genişlikleri ölçülmüştür.

Bulgular: Çalışmamıza 18-25 yaş arası 161 öğrenci (60 erkek, 101 kız öğrenci) dahil edilmiştir. Desen sınavinda elli ve üzerinde puan alan 49 k1z, 35 erkek öğrenci, kırk dokuz ve altında puan alan $52 \mathrm{k} 1 \mathrm{z}, 25$ erkek öğrenci bulunmaktadır. Çizim başarısı puanı elli ve üzerinde olan ile kırk dokuz ve altında olanların antropometrik özellikleri karşılaştırıldığında anlamlı fark elde edilememiştir.

Sonuç: Bu çalışma, çizim becerisine etki eden pek çok unsurun olduğu ve tek başına antropometrik standartlarla çizim başarısı arasındaki ilişkinin ifade edilmesinin zor olduğunu göstermiştir.

Anahtar kelimeler: El anatomisi, özel yetenek sinav1, resim, çizim başarısı. 


\section{GİRİŞ}

Sanat eğitiminde çizim becerisinin ölçülmesinde yaratıcilık, görme becerisi, algılama düzeyi, kavrama düzeyi, yaratıcı düşünme, doğru çizebilme yeteneği gibi yeterliliklerin yanı sıra bireyin sanatsal üretiminde el anatomisinin doğrudan etkisi olup olmadığ1 bugüne dek hep merak konusu olmuştur. Resim yaparken elin kalemi tutuş şekli, kalemi kavrama kuvveti, çizgiyi çizerken parmakların kaleme uyguladığı kuvvet, bileğin esnekliği ve hareket genişliği gibi elin antropometrik özelliklerinin hedeflenen çizimin bașarıya ulaşmasında etkisinin olabileceği düşünülmektedir1-3 ${ }^{1-}$

El bileği eklemi fleksiyon, extensiyon, ulnar deviasyon ve radial deviasyon hareketleri yapabilme yeteneğine sahip elipsoid tip bir eklemdir ${ }^{4}$. Elin proksimal bölümü olan el bileği, el ve önkol bileşkesini oluşturur. El bileği iskeleti, proksimalde ve distalde dörder adet olmak üzere, iki sıra üzerine dizilmiş sekiz adet karpal kemikten oluşur. Dorsal (arka) tarafta transvers yönde konveks, volar (ön) tarafta ise konkav bir yüzey oluşturarak sıralanan bu küçük kemikler el bileğine esneklik kazandırır ${ }^{5}$. El bileği mevcut 20 eklemi ve birbirinden bağımsız hareket edebilme kapasitesine sahip bölümleriyle vücudun en komplike eklemlerinden biridir ${ }^{6}$. El fonksiyon ve performansının değerlendirilmesi, kişinin günlük yaşam aktivitelerindeki beceri düzeyini tanımlamada, fonksiyonel etkinliği ve kişinin rol becerilerini ortaya koymada önem taşır ${ }^{7}$. El ile yapilan aktivitelerde fiziksel kapasitenin değerlendirilmesi, el fonksiyonunun değerlendirilmesiyle başlar. Eklem hareket genişliği, kas kuvveti, uzunluk, çevre, çap ve el kavrama kuvveti değerlendirme parametrelerindendir. El bileği eklemi hareketlerinin eklem hareket genişliği dereceleri yapılan aktivitelere göre farklilik göstermektedir.

Spor branşlarında Heimer ve arkadaşları ${ }^{8}$ temel ve spesifik antopometrik değerlendirilmesinin; Modver ve Foster de vücut ölçüsü oranı, fizik ve vücut kompozisyonun performansı etkileyen önemli faktörler olduğunu ifade etmiştir' ${ }^{9}$ Birçok spor dalında olduğu gibi voleybol sporunda da antropometrik ve somatotip özellikler sporcu performansıyla yakından ilgilidir. Her spor dalının kendine özgü fiziksel gereklilikleri vardır. Bu nedenle fiziksel ölçümler, antropometrik ve somatotip profiller bir sporcunun spor branşına uygunluğunu belirlemek için oldukça önemlidir ${ }^{10}$.
Dans alanında da Ayvazoğlu Bale Eğitimine uygunlukta vücut kompozisyonu (esneklik, dayanıklılık, eklem hareket genişliği, vücut ağırlı̆̆ı, çeviklik-denge vb.) ile birlikte alg1, müzik kulağ1 ve yüksek ritim duygusu gibi kriterlerin başta geldiğini belirtmiştir ${ }^{11,12}$

Müzik alanında, dirsekten itibaren ön kolun, bileklerin, parmakların ve enstrüman çalan kişinin vücut yapısına göre alacağ1 pozisyonun esnekliğinin, kuvvetinin ve duruşunun performansı etkilediğ bilinmektedir. Bu çıkarım, Gökbudak'ın ${ }^{13}$ bileğin piyano çalmak için gerekli olan teknik alışkanlıkların kazanılmasında da büyük rol oynadığını ve Uslu'nun $^{14}$ keman eğitimine gerekli olan unsurlara bakıldığında, bedenin doğru biçimde duruşuyla başlayan, devamında kemanı ve yayı doğru tutmak, kol, bilek, el ve parmakları doğru konuşlandırmak, sol el ve sağ el teknikleri gibi temel davranışlardan oluştuğunu ifade ettikleri çalışmalarıyla literatürde desteklenmektedir. Ayrıca, bilek, elin aşağı-yukarı, sağa-sola ve dairesel hareketler yapmasına da imkan tanır. Bu nedenle el bileğinin, aktif olarak kullanıldığı disiplin alanlarında etkin olduğu görülebilmektedir.

Görsel Sanatlar alanında ise Özsoy'15 "Yetenek Geliştirme Arac1 Olarak Görsel Sanatlar» isimli bölümünde Görsel sanatlarda motor gelişme ve fiziksel eşgüdümün (koordinasyon) atölye sürecindeki işlemlerde birbirine eşlik eden unsurlar olduğunu vurgulamıştır. Ayrıca "Sanat eserimizle daha iç içe geldiğimiz an, daha hassas oluruz ve firçayı, kalemi ya da keskiyi dikkatle kontrol etme ihtiyacını hissederiz. Bunu yaparken, göz ve el eşgüdümünü (koordinasyonunu) içeren küçük kas kuvvetleri geliştiririz ve böylece işçiliğimiz, ustalığımız ilerler." diyerek el antropometrisinin çizim becerisindeki etkisine dikkat çekmiștir. Bütün bu çalışmalar incelendiğinde müzik, dans ve spor branşlarında el antropometrisinin ve fiziksel özelliklerin yetenek seçimlerinde önemli bir etken olduğu belirtilmiş. Bu çalışma da Resim-İş Eğitimi özel yetenek sınavına giren adayların el anatomisinin (parmak uzunlukları, el bileği çap, çevre ve hareket genişliği ölçümleri) desen sınavında aldıkları puan ile ilişkisi olup olmadığını ortaya koymayı amaçlamıştır.

\section{GEREÇ VE YÖNTEM}

$\mathrm{Bu}$ çalıșma özel yetenek sınavina bașvuran öğrencilerin, çizim başarısı ve el antropometrik ölçümleriyle değerlendirilmelerini kapsamaktadır. Araştırmamız, deneysel bir çalışmadır. Çalışmamız, 
Çukurova Üniversitesi Eğitim Fakültesi Güzel Sanatlar Eğitimi Bölümü Resim-İş Eğitimi Anabilim Dalı Özel Yetenek Sınavı'nın yapıldığı 2015-2016 Eğitim-Öğretim dönemini kapsamaktadır. Çalışmamıza, bu dönemde Yetenek Sınavı için ön kayıt yaptıran 18-25 yaş arası 161 öğrenci (60 erkek, 101 kız öğrenci ) dâhil edilmiştir. Çalışmamız için Çukurova Üniversitesi Eğitim Fakültesi Güzel Sanatlar Eğitimi Bölümü Resim-İş Eğitimi Anabilim Dalı Başkanlığı'ndan izin ve Çukurova Üniversitesi Tıp Fakültesi Girişimsel Olmayan Klinik Araştırmalar Etik Kurulu'ndan (tarih; 02 Mart 2018, say1; 75, karar no; 55) da onay alınmıştır. Katılımcılara gönüllü onam formu imzalatılmıştır.

17-18-19 Ağustos 2015 Özel Yetenek Sinavı ön kayıt tarihlerinde, ölçüm düzeneği prosedüre göre kurulmuş, denek takip formları, gönüllü onam formları ve aletler (Tablo 2) hazırlanmıştır. Sınava başvuru yapan tüm öğrenciler, bașvuru yaptıkları salondan ölçüm yapılan salona yönlendirilip, sınav jürisinden bağımsız bir şekilde araştırmacılar tarafindan Tablo 1' de yer alan prosedüre göre ölçümler yapılmıştır. Ölçümler sonrasında, sınav jürisi ile hiçbir şekilde ölçüm sonuçları hakkında görüşme yapılmamış, ölçümler ve sonuçlar gizli tutulmuştur. Bu sayede değerlendirmeleri etkileyecek yanlılıktan kaçınılmışır. Analiz yapılırken ilan edilen sonuçlar, Çukurova Üniversitesi Eğitim Fakültesi Güzel Sanatlar Eğitimi Bölümü Resim-Işs Eğitimi Anabilim Dalı resmi sitesinden öğrenilmiştir.

Çizim başarısı ise, sınava ön kayıt yaptıran adayların, 24 Ağustos 2015 tarihinde Çukurova Üniversitesi Eğitim Fakültesi Güzel Sanatlar Eğitimi Bölümü Resim-İş Eğitimi Anabilim Dalı'nın gerçekleştirdiği Özel Yetenek Sinavi esnasinda canlı modelden desen çizimi sonucunda aldığı puanı kapsamaktadır.

Tablo 1. Antropometrik ölçümler ve değerlendirme yöntemleri

\begin{tabular}{|c|c|}
\hline Ölçüm & Değerlendirme yöntemi: \\
\hline 1.Parmak uzunluğu & $\begin{array}{l}\text { El içindeki 1. parmağın bazal kıvrımından parmak distaline kadar olan } \\
\text { sınırlardan ölçülecektir }{ }^{16} \text {. }\end{array}$ \\
\hline 2.Parmak uzunluğu & $\begin{array}{l}\text { El içindeki 2. parmağın bazal kıvrımından parmak distaline kadar olan } \\
\text { sınırlardan ölçülecektir }{ }^{16} \text {. }\end{array}$ \\
\hline 3.Parmak uzunluğu & $\begin{array}{l}\text { El içindeki 3. parmağın bazal kıvrımından parmak distaline kadar olan } \\
\text { sınırlardan ölçülecektir }{ }^{16 .}\end{array}$ \\
\hline 4.Parmak uzunluğu & $\begin{array}{l}\text { El içindeki 4. parmağın bazal kıvrımından parmak distaline kadar olan } \\
\text { sınırlardan ölçülecektir } 16 .\end{array}$ \\
\hline 5.Parmak uzunluğu & $\begin{array}{l}\text { El içindeki 5. parmağın bazal kıvrımından parmak distaline kadar olan } \\
\text { sınırlardan ölçülecektir }{ }^{16} \text {. }\end{array}$ \\
\hline El uzunluğu & $\begin{array}{l}\text { Parmaklar adductio ve extensio pozisyonundayken radius' un processus } \\
\text { styloideus radii çlkıntısının distali ile 3. parmağın ucu arasındaki uzaklık elin } \\
\text { dorsalinden ölçülmüştür }{ }^{17} \text {. }\end{array}$ \\
\hline El bileği çevresi & Radius ve ulna' nın processus styloideus' u arasındaki çevre ölçülmüştür ${ }^{17}$. \\
\hline El bileği çap1 & Radius ve ulna' nın processus styloideus' u arasındaki uzaklık ölçülmüştür ${ }^{17}$. \\
\hline El fleksiyonu & $\begin{array}{l}\text { Alet ulnanın stiloid çıkıntısına yerleştirilir. El fleksiyona getirilirerek } \\
\text { ölçülecektir }{ }^{17} \text {. }\end{array}$ \\
\hline El extensiyon & $\begin{array}{l}\text { Alet ulnanın stiloid çıkıntısına yerleştirilir. El extensiyona getirilirerek } \\
\text { ölçülecektir }{ }^{17} \text {. }\end{array}$ \\
\hline El abduksiyon & $\begin{array}{l}\text { Alet 3. metakarpalin proksimaline, karpometakarpal eklemin orta noktasına } \\
\text { yerleştirilerek radial deviasyon yaptırllarak ölçülecektir }{ }^{17} \text {. }\end{array}$ \\
\hline El adduksiyon & $\begin{array}{l}\text { Alet 3. metakarpalin proksimaline, karpometakarpal eklemin orta noktasına } \\
\text { yerleştirilerek ulnar deviasyon yaptırılarak ölçülecektir }{ }^{17} \text {. }\end{array}$ \\
\hline El kuvveti & $\begin{array}{l}\text { Deneğe, el dinamometresini vücuduna değdirmemesi, vücudundan uzak } \\
\text { tutmasi talimatı verilerek, en az } 2 \text { saniye boyunca dinamometrenin sıkılması } \\
\text { gerektiği konusunda uyarılarak uygulanacaktır }{ }^{8} \text {. }\end{array}$ \\
\hline
\end{tabular}

Sinav öncesinde; ön kayıt yaptıran adayların soy isimleri alfabetik olarak sıralanarak, 15'er kişilik grup listesi oluşturulmuştur. Adayların hangi salonda sınava gireceği kapıya asılan listeyle adaylara duyurulmuş ve sınav esnasinda adayı kontrol etmek için de gözetmenlere adayın resminin yer aldığ kontrol listesi verilmiştir. Adaylara verilecek çizim kâğıdı, sol üst köşesi içeri katlanıp, üzeri 
mühürlenerek hazır hale getirilmiştir. Oturma düzeni ise, adayların modeli her açıdan görebileceği şekilde 15 'er kişilik toplam 10 salondan oluşturulmuştur. Her salona iki gözetmen yerleştirilmiştir. Sinav sürecinde; adaylar güvenlik kontrolünden geçerek, kimlik kontrolleri yapılarak salonlara alınmış ve her adaya önceden hazırlanan mühürlü kâğıtlar gözetmenler tarafindan dağıtılmıştır. Adaylardan, kâğıdın sol üst köşesine ön kayıt esnasında kendilerine verilen aday numaralarını yazarak, imza atmaları istenmiştir. Sonra da her salonda görevli olan gözetmenler aracılığıyla kâğıdın katlı köşesinden bantlanarak gizlilik sağlanmıştır. Böylece sınav jürisi, değerlendirmeyi yaptığı sırada adayların isim ya da aday numarasını görmemiştir. Sınav süresi, toplamda 100 dakikadır ve sinav, her salonda aynı anda başlatılıp, aynı anda bitirilmiştir. Sınav boyunca sınavı değerlendirecek jüri üyeleri salonlara girmiştir. Sınav kâğıtları sınav bitiminde gözetmenler tarafindan jürilere ulaştırılmıştır. Böylece sınavın sağlıklı yürütülmesi sağlanmıştır.

Tablo 2. Ölçümler ve kullanılan gereçler

\begin{tabular}{|l|l|}
\hline Ölçümler & Kullanılan Aletler: \\
\hline Çevre ölçümü & 2 m esnek olmayan mezura \\
\hline Çap ve uzunluk ölçümü & $\begin{array}{l}\text { Super Big Screen digital } \\
\text { Caliper (BTS) }\end{array}$ \\
\hline $\begin{array}{l}\text { Eklem hareket genişliği } \\
\text { ölçümü }\end{array}$ & $\begin{array}{l}\text { Acumar digital inklinometre } \\
\text { model; ACU001 }\end{array}$ \\
\hline Kuvvet & $\begin{array}{l}\text { Lafayette marka el } \\
\text { dinamometresi model; 78010 }\end{array}$ \\
\hline
\end{tabular}

Sinavin değerlendirilmesi; ilk olarak adaylardan toplanan mühürlü kâğıtlara jüri üyeleri tarafindan rastgele 1'den başlayarak numaralar verilmesi ile başlanmıştır. Adayın çizim başarı puanı, 100 tam puan üzerinden beş jüri üyesinin vermiş olduğu puanların, toplanarak ortalamasinın alınmasıyla elde edilmiştir. Jüri üyeleri, desen sınavinda adayın yapmış olduğu çizimi, görme becerisi, oran-orantı, kompozisyon bütünlüğü, çizgi değerleri, denge, alg1lama düzeyi gibi nitelikleri üzerinden değerlendirerek birbirinden bağımsız olarak puanlamıştır. Beş jüri üyesinin puanlama yaptı̆̆1 çizelge, excel ortamına aktarılıp, ortalamalar alınarak adayların ortalama puanı elde edilmiştir. Sonra her adayın kâğıtların üzerine ortalama puan yazılmıştır. En son kâğıtlar bantlı yerlerinden açılarak puanın hangi adaya ait olduğu kesinleşmiş ve sonuç listesi hazırlanarak puanlar yüksekten düşük puana göre sıralanmıştır. Sonuç puanları resmi sitede ilan edilmiştir.

\section{İstatistiksel analiz}

Çalışmada sürekli değişkenler için tanımlayıcı istatistikler ortalama \pm standart sapma, şeklinde özetlenmiştir. Verilerin normal dağılıma uygunluğu histogram ile test edilip, duruma uygun olarak parametrik veya parametrik olmayan yöntemler seçilmiştir. Bağımsız grup karşılaştırmalarında "Independent- Samples t testi ve Mann-Whitney U testi” bağımlı grup karşılaştırmalarında ise “ Eşleştirilmiş Student t testi ve Wilcoxon testi” kullanılmıştır. Erkek ve kız öğrencilerin desen puanları ve antropometrik değerleri arasındaki ilişki ise Pearson korelasyon analizi ile değerlendirilmiştir. Anlamlılık düzeyi $\mathrm{p}<0.05$ olarak alınmıştır. Çalışmada elde edilen verilerin istatistiksel analizleri için IBM SPSS version 19 paket programı kullanılmıştır.

\section{BULGULAR}

Çalışmamıza 18-25 yaş arası 161 öğrenci (60 erkek, 101 kız öğrenci ) dahil edilmiştir. Parmak uzunlukları, el uzunluğu, el bileği çapı ve çevresi ile el kuvveti ve eklem hareket genişliği derecelerinin ortalama (Ort) ve standart sapma (SS) değerleri Tablo 3 ve Tablo 4'de, desen sınavı sonuçları ve antropometrik ölçümler arasındaki ilişki (r) ise Tablo 5 ve Tablo 6'da özetlenmiștir. Desen sinavinda elli ve üzerinde puan alan 49 kız, 35 erkek öğrenci, kırk dokuz ve altında puan alan 52 kız, 25 erkek öğrenci bulunmaktadır. Kız öğrencilerin desen sınav puanı ile el antropometrisi parametrelerinin ortalama değerleri incelendiğinde, uzunluk çap ve çevre ölçümlerinde 5. Parmak uzunluğu hariç diğer parametrelerde 50 puan ve üzerinde alan k1z öğrencilerin değerlerinde anlamlı fark elde edilmemiş olup daha yüksek bulunmuştur (Tablo 3). Erkek ögrencilerin desen sınav puanı ile el antropometrisi parametrelerinin ortalama değerleri incelendiğinde ise uzunluk çap ve çevre ölçümlerinde el uzunluğu ve el bileği çevresi hariç diğer parametrelerde 50 puan ve üzerinde alan erkek öğrencilerin değerlerinde anlamlı fark elde edilmemiş olup daha yüksek bulunmuştur (Tablo 4). Bu sonuçlar ışığında çok iddialı olmamakla birlikte parmakları uzun olanların çizimde daha başarılı olabileceği söylenebilir. Erkek ve kız öğrencilerin desen sınav puanı ile el antropometrisi arasındaki ilişki incelendiğinde düşük düzeyde negatif korelasyon elde edilmiştir (Tablo5, Tablo 6). 
Tablo 3. Kız öğrencilerin desen sınav puanı ile el antropometrisi parametrelerinin ortalama değerleri

\begin{tabular}{|l|c|c|c|c|}
\hline \multirow{2}{*}{ Parametreler } & \multicolumn{2}{|c|}{ 50 Puan ve Üzeri (n:49) } & \multicolumn{2}{c|}{ 49 Puan ve Alt1 (n:52) } \\
\cline { 2 - 5 } & Ort. & Std & Ort. & Std. \\
\hline 1.Parmak uzunluğu & 6.80 & 0.46 & 6.50 & 0.49 \\
\hline 2.Parmak uzunluğu & 7.00 & 0.50 & 6.98 & 0.48 \\
\hline 3.Parmak uzunluğu & 7.60 & 0.48 & 7.54 & 0.54 \\
\hline 4.Parmak uzunluğu & 6.90 & 0.40 & 6.89 & 0.48 \\
\hline 5.Parmak uzunluğu & 5.70 & 0.45 & 5.74 & 0.45 \\
\hline El uzunluğu & 9.80 & 0.70 & 9.77 & 0.66 \\
\hline El bileği çevresi & 16.50 & 1.36 & 15.92 & 1.31 \\
\hline El bileği çap1 & 5.00 & 0.30 & 4.97 & 0.29 \\
\hline El fleksiyonu & 76.40 & 8.75 & 77.78 & 6.83 \\
\hline El extensiyon & 69.40 & 6.18 & 72.43 & 6.17 \\
\hline El abduksiyon & 40.10 & 4.99 & 41.03 & 6.50 \\
\hline El adduksiyon & 22.00 & 6.10 & 22.23 & 4.70 \\
\hline El kuvveti & 25.0 & 4.72 & 24.92 & 5.36 \\
\hline
\end{tabular}

Tablo 4. Erkek öğrencilerin desen sınav puanı ile el antropometrisi parametrelerinin ortalama değerleri

\begin{tabular}{|l|c|c|c|c|}
\hline \multirow{2}{*}{ Parametreler } & \multicolumn{2}{|c|}{ 50 Puan ve Üzeri (n:35) } & \multicolumn{2}{c|}{ 49 Puan ve Alt1 (n:25) } \\
\cline { 2 - 5 } & Ort. & Std. & Ort. & Std. \\
\hline 1.Parmak uzunluğu & 7.31 & 0.60 & 7.16 & 0.57 \\
\hline 2.Parmak uzunluğu & 7.55 & 0.36 & 7.46 & 0.52 \\
\hline 3.Parmak uzunluğu & 8.20 & 0.49 & 8.04 & 0.56 \\
\hline 4.Parmak uzunluğu & 7.61 & 0.47 & 7.52 & 0.55 \\
\hline 5.Parmak uzunluğu & 6.32 & 0.44 & 6.21 & 0.47 \\
\hline El uzunluğu & 10.84 & 0.55 & 10.94 & 0.73 \\
\hline El bileği çevresi & 17.79 & 1.13 & 18.21 & 0.98 \\
\hline El bileği çap1 & 5.57 & 0.36 & 5.54 & 0.27 \\
\hline El fleksiyonu & 75.91 & 9.18 & 72.77 & 12.33 \\
\hline El extensiyon & 69.08 & 9.44 & 67.18 & 8.97 \\
\hline El abduksiyon & 41.73 & 5.93 & 40.99 & 4.97 \\
\hline El adduksiyon & 24.41 & 6.92 & 23.52 & 8.52 \\
\hline El kuvveti & 37.77 & 8.61 & 35.64 & 8.57 \\
\hline
\end{tabular}

Tablo 5. Kız öğrencilerin desen sınav puanı ile el antropometrisi arasındaki ilişki

\begin{tabular}{|c|c|c|c|c|}
\hline \multirow[t]{2}{*}{ Parametreler } & \multicolumn{2}{|c|}{50 Puan ve Üzeri (n:49) } & \multicolumn{2}{|c|}{49 Puan ve Altı (n:52) } \\
\hline & $\mathrm{P}$ & $\mathrm{R}$ & $\mathrm{P}$ & $\mathrm{R}$ \\
\hline 1.Parmak uzunluğu & 0.06 & -0.26 & 0.46 & 0.10 \\
\hline 2.Parmak uzunluğu & 0.92 & 0.01 & 0.28 & -0.15 \\
\hline 3.Parmak uzunluğu & 0.48 & -0.10 & 0.35 & -0.13 \\
\hline 4.Parmak uzunluğu & 0.34 & -0.13 & 0.52 & -0.09 \\
\hline 5.Parmak uzunluğu & 0.33 & -0.14 & 0.15 & -0.20 \\
\hline El uzunluğu & 0.19 & -0.19 & 0.32 & -0.14 \\
\hline El bileği çevresi & 0.62 & -0.07 & 0.14 & -0.20 \\
\hline El bileği çap1 & 0.17 & -0.19 & 0.04 & -0.27 \\
\hline El fleksiyonu & 0.44 & 0.11 & 0.001 & 0.04 \\
\hline El extensiyon & 0.56 & 0.08 & 0.25 & 0.16 \\
\hline El abduksiyon & 0.67 & 0.06 & 0.83 & -0.02 \\
\hline El adduksiyon & 0.08 & -0.24 & 0.05 & -0.26 \\
\hline El kuvveti & 0.79 & -0.03 & 0.94 & -0.01 \\
\hline
\end{tabular}


Tablo 6. Erkek Öğrencilerin Desen Sınav Puanı ile El Antropometrisi Arasındaki İlişki

\begin{tabular}{|l|l|l|l|l|}
\hline Parametreler & \multicolumn{2}{|l|}{$\mathbf{5 0}$ Puan ve Üzeri (n:35) } & \multicolumn{2}{l|}{ 49 Puan ve Alt1 (n:25) } \\
\hline & P** & $\mathrm{R}$ & P** & $\mathrm{R}$ \\
\hline 1.Parmak uzunluğu & 0.20 & -0.22 & 0.98 & -0.04 \\
\hline 2.Parmak uzunluğu & 0.01 & -0.41 & 0.74 & 0.06 \\
\hline 3.Parmak uzunluğu & 0.67 & -0.07 & 0.95 & 0.01 \\
\hline 4.Parmak uzunluğu & 0.64 & -0.08 & 0.46 & 0.15 \\
\hline 5.Parmak uzunluğu & 0.19 & -0.23 & 0.50 & -0.14 \\
\hline El uzunluğu & 0.15 & -0.24 & 0.81 & 0.05 \\
\hline El bileği çcvresi & 0.24 & -0.20 & 0.30 & 0.21 \\
\hline El bileği çap1 & 0.40 & -0.14 & 0.98 & -0.05 \\
\hline El fleksiyonu & 0.20 & 0.21 & 0.99 & 0.0 \\
\hline El extensiyon & 0.61 & 0.08 & 0.81 & -0.04 \\
\hline El abduksiyon & 0.44 & -0.13 & 0.38 & 0.18 \\
\hline El adduksiyon & 0.17 & -0.23 & 0.73 & 0.07 \\
\hline El kuvveti & 0.43 & -0.13 & 0.25 & 0.23 \\
\hline
\end{tabular}

\section{TARTIŞMA}

Sanat eğitiminde çizim becerisinin ölçülmesinde yaratıcılık, görme becerisi, algilama düzeyi, kavrama düzeyi, yaratıcı düşünme, doğru çizebilme yeteneği gibi yeterliliklerin yanı sira bireyin sanatsal üretiminde el anatomisinin doğrudan etkisi olup olmadığ1 bugüne dek hep merak konusu olmuştur. Resim yaparken elin kalemi tutuş şekli, kalemi kavrama kuvveti, çizgiyi çizerken parmakların kaleme uyguladığı kuvvet, bileğin esnekliği ve hareket genişliği gibi elin antropometrik özelliklerinin hedeflenen çizimin başarıya ulaşmasında etkisinin olabileceği düşünülmektedir ${ }^{1-}$ 3. Bu çalışma adayların el, parmak, bilek gibi çizim yapmasına etki eden uzuvlarının anatomik yapısının özel yetenek sınavında etkisi olup olmadığını ortaya çıkarması açısından önemlidir.

Çalışmamızda ele ait uzunluk, çap, çevre, el bileği eklem hareket genișlikleri ve el kavrama kuvvetini değerlendirdik. Eklem hareket genişliği el bileğinin esnekliğini, hareket kabiliyetini, el kavrama kuvveti ise mesleki becerilerin değerlendirilmesinde önemli yol gösterici parametrelerdir.

$K_{1 z}$ öğrencilerin desen sinav puanı ile el antropometrisi parametrelerinin ortalama değerleri incelendiğinde, elli puan üzerindeki kızlarda 5 . Parmak uzunluğu, fleksiyon, ekstensiyon, abduksiyon ve adduksiyon değerleri dışında bütün parametreler yüksek bulunmuştur (Tablo 3). Erkek ögrencilerin desen sinav puanı ile el antropometrisi parametrelerinin ortalama değerlerine bakıldığında ise elli puan ve üzerindeki erkeklerde el uzunluğu, el bileği çevresi dişındaki parametreler yüksek bulunmuştur (Tablo 4). Ancak parametreler arasındaki fark çok az olduğu için el anatomisinin çizim başarısındaki etkisi doğrudan söylenemez.

Kız öğrencilerin desen sinav puanı ile el antropometrisi arasındaki ilişki değerlendirildiğinde, kırk dokuz puan ve altındaki öğrencilerde, el bileği çap1 ve adduksiyon parametrelerinde negatif yönde, fleksiyon parametresinde ise pozitif yönde anlamlı ilişki saptanmıştır (Tablo 5). Erkek öğrencilerin desen sinav puanı ile el antropometrisi arasındaki ilişki incelendiğinde ise elli puan ve üzerindeki erkek öğrencilerin 2. Parmak uzunlukları arasında negatif yönde anlamlı ilişki bulunmuştur (Tablo 6). Her iki cinsiyette ise diğer parametrelerde düşük derecede negatif ilişki saptanmıştır. Öğrencilerin desen sınavinda almış oldukları puanlama ve antropometrik ölçümler arasında anlamlı bir ilişki bulunamamıştır (Tablo5, Tablo 6). Bazı parametrelerde düşük derecede pozitif ya da negatif korelasyon bulunması resim alanina uygunlukta antropometrik ölçümlerin belirleyici faktörler olarak ileri sürülmesinin zor olduğunu göstermiştir. Çizim ya da resim yapma becerisi aynı zamanda görme, algılama, hayal gücü, yaratıcılık gibi çok boyutlu yetileri barındıran ve bu yetilerle eş güdümlü olarak hareket edilerek ortaya çıkan bir süreçtir. Çizim yapmak sadece bir kalem tutmak ve kağıt üzerine kalemi hareket ettirerek işaretler yaratmak kadar basit bir şey gibi görünse de bu işaretlerin bir şeye benzetilmesi, öykünün yaratılması ve yaratıcıllı̆ın öne çıkarılması bambaşka bir durumdur.

Literatürde bu alanda yapılan çalışmalara çok az 
rastlanmış olup, çizim başarısına etki eden faktörlerin incelendiğ çalışmalara bakıldığında Monika'nın Design \& Illustration dergisinde yayınlanan çizim teorisi hakkındaki yazısında, elin hareketini bile hesaba katmadan çizim konusuna odaklanırken, güzel şeyler yaratmak için bireyin kendini rahat hissetmesinin kimi zaman tek başına yeterli olabileceğini ifade etmiştir 19. Monika, "Elinizin hareketinin, yapıtınızın kalitesi üzerinde herhangi bir etkisi olur mu? Bileğini kullanıyorsan gerçekten daha kötü bir sanatçı mısın? Çoğunluk yanlış $\mathrm{m}$ biliyor? " gibi sorularla durumu anlamaya çalışmıştır 19. Monika yapmış olduğu anket çalışmasında başlangıç çizimine etki eden dört olasılık (bilek, dirsek, omuz ve aslında tüm vücut) üzerinde durmuştur. Bilekten çizim de, kalemi küçük bir yüzeyde yavaş ve kısıtlı bir şekilde hareket ettirildiğini, çizimin ayrıntısının tamamlanabildiğini, dirsek ve omuzdan çizim de ise, kalemi daha geniş bir yüzeyde hareket ettirip resmin genel hatlarının verildiğini ve daha büyük bir alanda çalışıldığını vurgulamıştır. Bilekten çizim yapmanın yeni başlayanlar için olduğu sonucuna da varılmıştır. Bunun gerekçesini ise bileğin geniş şekillerin yaratılmasında sınırlı çizim alanı oluşturarak, çizim hareketini kısıtlaması olarak açıklamıştır 19. Çalışmamızda çizim başarısı elli puan ve üzeri ile kırk dokuz puan ve altı olan adayların el bileği eklem hareket genişliği parametrelerinde birbirine yakın değerler bulunması el bileğinin çizim yüzeyi üzerinde kısıtlı hareket sağlamasından kaynaklandığını düşünmekteyiz. Monika'nın çalışmas ${ }^{19}$ da bu görüşü desteklemektedir.

Dounskaia ve arkadaşları 20 ise, çizim yapanların hareketlerini inceledikleri araştırmalarını omuz ve dirsekle sınırlandırarak işe başlamışlardır. $\mathrm{Bu}$ durumu, bileğin geniş şekillerin yaratılmasında sınırlı alanının olmasının çizim hareketini kısıtlamasına neden olacağ1 gerekçesiyle açıklamışlardır. Bu bilgilerden yola çıkarak el, bilek, dirsek, omuz gibi uzuvların antropometrik özelliklerinin çizimdeki ilişkisi öngörülebilir. Ancak çizim başarısında sadece antropometrik özelliklerin belirleyici bir faktör olduğunu öne sürmek yanlış olur. Çalışmamızdan elde edilen sonuçlarda bu görüşü destekler niteliktedir. $\mathrm{Bu}$ nedenle çizim ya da resim yapma becerisini tek başına antropometrik özelliklerle değerlendirmek doğru sonuçlar doğurmayabilir ${ }^{21}$.

Özsoy ${ }^{15}$ çalışmasında, çizim yaparken göz ve el eşgüdümünü (koordinasyonunu) içeren küçük kas kuvvetleri geliştirildiğini ve böylece işçiliğin, ustalığın ilerlediğini vurgulamıstır. Tchalenko ve Miall 22 ise çizim esnasında el-göz koordinasyonunun önemini çalışmalarıyla açıklamıştır. Bütün bu sonuçlardan yola çıkarak, çizim becerisine etki eden pek çok unsurun olduğu ve tek başına antropometrik standartlarla çizim başarısı arasındaki ilişkinin ifade edilmesinin zor olduğu söylenebilir.

Sınırlılıklar; Çalışmamız sadece bir sınav dönemini kapsamaktadır o nedenle genel iddialarda bulunacağımız sayısal çoğunluk sağlanamamıştır. Değerlendirme kapsamına aldığımız sınav sadece bir üniversiteye aittir. Her üniversitenin puanlama sistemi sınav düzeneği ve jürileri farklıdır. Bu durum genelleme yapmamıza engel oluşturmaktadır. Bu nedenle birçok üniversitenin dahil edildiği ve birden fazla sınav döneminin değerlendirildiği çalışmaların yapılmasıyla hem sayısal çoğunluğun elde edilmesine, hem de bu tarz sinavlarda bir standardin oluşturulmasına katkı sağlanacağını düşünekteyiz. Ayrıca eğitim süreci içerisinde öğrencilerin anatomik değişimlerinin değerlendirilerek gelişimleri izlenebilir. Bu nedenle eğitim sürecinin başlangıcı ve sonucundaki antropometrik değerleri kıyaslanarak anlamlı fark elde edilebilecek çalışmaların yapılmasını önermekteyiz. Literatüre baktı̆ııııda çizim için el bileği, dirsek ve omuz hareketlerinin öneminden bahsedilmiştir ${ }^{19-20}$. Çalışmamızda sadece el bileği eklem hareket genişliği parametrelerine yer verilmiştir. Bilek, dirsek ve omuzdan çizim üzerine yapılan incelemeler dikkate alındığında, daha büyük bir örneklem grubu ile daha fazla sayıda parametrenin değerlendirildiği benzer çalışmaların yapılması önerilmektedir.

\section{KAYNAKLAR}

1. Yilmaz A, Mesut R. Artistik anatomi- bilim ve sanatın ortak ürünü. Sürekli Tip Eğitimi Etkinliği. 2008;73-84.

2. Yücel H, Kayıhan H. Elin fiziksel özelliklerinin el fonksiyonu üzerine etkileri. Fizyoterapi Rehabilitasyon. 2008;19:24-9.

3. Açıkgöz S. İlköğretim okullarında öğrenim gören bedensel engelli ögrencilerin resimlerinin sanatsal gelişim aşamaları yönünden incelenmes (Yüksek lisans tezi). Konya, Selçuk Üniversitesi, 2009.

4. Dere F. Anatomi Atlas1 ve Ders Kitab1. 5. Bask1. Adana, Nobel Tip Kitabevi, 2010.

5. Moore KL. Clinical Oriented Anatomy, 5th ed. Baltimore, Lippinccott Williams \& Wilkins, 2006.

6. McCann PA, Amirfeyz R, Wakeley C, Bhatia R. The volar anatomy of the distal radius-an MRI study of the FCR approach. Injury. 2010;41:1012-4. 
7. Williams ME, Hadler NM, Earp JA. Manuel ability as a marker of dependency in geriatric women. J Chronic Dis. 1982;35:115-22.

8. Heimer S, Misigoj M, Medved V. Some anthropological of top volleyball players in Yugoslavia. J Sports Med Phys Fitness. 1988;28:2008.

9. Maud PJ, Foster C. Physiological Assessment of Human Fitness. USA, Human Kinetics, 1995.

10. Ergen E, Gambuli N, Leonardi L, Dal Monte A. Relationships between body composition, leg strength and maximal alactacid anaerobic power in trained subjects. J Sports Med Phys Fitness. 1983;23:399-403.

11. Ayvazoğlu S. Active dance life of ballet artists in turkey and their problems. Süleyman Demirel Üniversitesi Güzel Sanatlar Fakültesi Hakemli Dergisi. 2012;09:39-54.

12. Ayvazoğlu S. Okul Öncesi Dönemde Bale Eğitimi. Ankara, Akademisyen Kitabevi, 2013.

13. Gökbudak ZS, Tutun Mİ. Piyano eğitiminde bilek kullanımının önemi. Selçuk Üniversitesi Sosyal Bilimler Enstitüsü Dergisi. 2005;14:289-99.

14. Uslu M. Nitelikli keman eğitimine yönelik yaklaşımlar. Journal of Research in Education and Teaching. 2012;1:1-11.

15. Özsoy, V. Resim-İş Eğitiminin Tarihsel ve Düşünsel Temelleri. Ankara, Gündüz Eğitim ve Yayıncllı, 2007.
16. Öztaşan N, Kutlu N. Sağlıklı bireylerde parmak uzunluk oranlarının (2d: $4 \mathrm{~d})$; el tercihi, nonverbal zeka, görsel, işitsel ve verbal yetenekler, motor beceri ve serebral lateralizasyon ile ilişkisi. Balıkesir Sağlık Bilimleri Dergisi. 2014;3:11-5.

17. Otman AS, Köse N. Tedavi Hareketlerinde Temel Değerlendirme Prensipleri. Ankara, Pelikan Kitabevi, 2014.

18. Hasan K. Edirne iline bağlı ilkokullardaki (Şehit Asım ilköğretim okulu ve Trakya üniversitesi devlet konservatuvarı ilköğretim okulu) 8-11 yaş arasındaki öğrencilerin eurofit testleri ile fiziksel kondisyonlarının değerlendirilmesi (Yüksek lisans tezi). Edirne, Trakya Üniversitesi, 2008.

19. Zagrobelna M, Drawing from the Shoulder vs. Drawing from the Wrist: Pros and Cons. Erişim; https://design.tutsplus.com/articles/drawing-fromthe-shoulder-vs-drawing-from-the-wrist-pros-andcons--cms-24173. Erișim Tarihi; 07.02.2018.

20. Dounskaia N, Ketcham CJ, Stelmach GE. Commonalities and differences in control of various drawing movements. Exp Brain Res. 2002;146:1125.

21. Posture and movement control for drawing and handwriting. Erişim; https://skillsforaction.com/handwriting/motorcontrol. Erişim Tarihi;07.02.2018.

22. Tchalenko J, Miall RC. Eye-hand strategies in copying complex lines. Cortex. 2009;45:368-76. 